\title{
Pengaruh Good Governance dan Motivasi Kerja Terhadap Kinerja Manajerial Penyelenggara Pemerintahan Desa di Kabupaten Badung
}

\author{
Anak Agung Mas Prabha Iswara ${ }^{1}$ \\ Fakultas Ekonomi dan Bisnis \\ Universitas Udayana, Indonesia. \\ Email: prabhaiswara98@gmail.com
}

\author{
I. G. A. M. Asri Dwija Putri² \\ Fakultas Ekonomi dan Bisnis \\ Universitas Udayana, Indonesia.
}

\begin{abstract}
ABSTRAK
Tujuan dari penelitian ini untuk mengetahui pengaruh good governance dan motivasi kerja terhadap kinerja manajerial penyelenggara pemerintahan desa di Kabupaten Badung. Penelitian ini dilakukan di Kabupaten Badung dengan responden sebanyak 230 orang penyelenggara pemerintahan desa. Penentuan sampel menggunakan non probability sampling dengan teknik sampling jenuh. Metode pengumpulan data dilakukan dengan menggunakan kuesioner dan teknik analisis data menggunakan analisis regresi linear berganda. Hasil penelitian ini menunjukkan bahwa variabel Good Governance dan Motivasi Kerja berpengaruh positif terhadap Kinerja Manajerial Penyelenggara Pemerintahan Desa di Kabupaten Badung.
\end{abstract}

Kata Kunci: Good Governance; Motivasi Kerja; Kinerja Manajerial.

The Effect of Good Governance and Work Motivation on Managerial Performance of Village Government Officials in Badung Regency

\section{ABSTRACT}

The aim of this research is to know how influence good governance and work motivation in managerial performance of government officials in Badung Regency. The sample of this study is 230 respondents from the village officials of Badung Regency. Determination of the sample using non-probability sampling with saturation sampling technique. To collect the data, the researcher using questionnaires and data analysis techniques using multiple linear regression analysis. The result of the data showed that Good Governance and Work Motivation variables have a positive effect on the Managerial Performance of Village Government Officials in Badung Regency.

Keywords: Good Governance; Work Motivation; Managerial Performance.

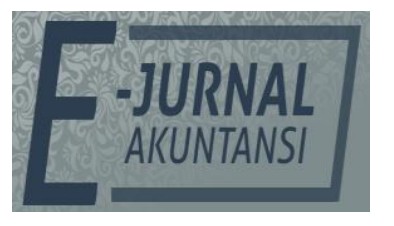

E-JA

e-Jurnal Akuntansi e-ISSN 2302-8556

Vol. 29 No. 2

Denpasar, November 2019

Hal. 618-629

Artikel masuk: 09 Oktober 2019

Tanggal diterima: 11 November 2019 


\section{PENDAHULUAN}

Sejak berlakunya Undang-Undang Republik Indonesia Nomor 6 Tahun 2014 Tentang Desa maka mempertegas istilah otonomi daerah. Dalam konteks otonomi daerah, daerah diberi wewenang dan tanggung jawab dalam mengelola sumber-sumber keuangan untuk menjamin kemakmuran rakyatnya. Peraturan tersebut juga didukung oleh program Nawa Cita. Program tersebut terdapat salah satu pernyataan yakni membangun Indonesia dari pinggiran dengan memperkuat daerah-daerah dan desa dalam kerangka negara kesatuan. Secara tidak langsung peraturan tersebut memberi peluang bagi suatu desa agar dapat mengatur dana desa yang diberikan secara mandiri. Sehingga potensi yang dimiliki desa tersebut dapat dikembangkan untuk mensejahterakan masyarakatnya.

Lima tahun terakhir, sejak tahun 2015 pengalokasian dana desa mulai ditingkatkan dari tahun ke tahun. Berikut ini rincian pembagian dana desa khususnya di Kabupaten Badung dalam lima tahun terakhir dapat dilihat pada Tabel 1.

Tabel 1. Pembagian Dana Desa Provinsi Bali

\begin{tabular}{lcccccc}
\hline Nama Daerah & $\begin{array}{c}\text { Jumlah } \\
\text { Desa }\end{array}$ & 2015 & 2016 & 2017 & 2018 & 2019 \\
\hline Kab. Badung & 46 & $13,826,342$ & $31,046,783$ & $40,315,619$ & 42.439 .183 & 52.584 .767 \\
\hline
\end{tabular}

Sumber: www.kemenkeu.go.id, 2019

Tabel 1 menunjukkan angka dalam ribu rupiah, bahwa di tahun 2019 Kabupaten Badung menempati urutan ke-6 dalam pengalokasian dana desa yakni sebesar Rp 52.584.767.000. Dengan luas teritorial 418,52 (7,42\%) yakni menempati urutan ke-6 dari sembilan Kabupaten dan Kota di Provinsi Bali (bali.bps.go.id:2018). Namun pengelolaan alokasi dana desa tersebut masih kurang maksimal dengan tujuan pengalokasian dana desa, yakni untuk membiayai program pemerintah desa dalam melaksanakan kegiatan pemerintah dan pemberdayaan masyarakat. Meskipun dalam lima tahun terakhir tersebut dana desa yang diberikan selalu meningkat, tetapi tetap saja ditemukan permasalahan terkait kinerja pemerintah.

Sejak lima tahun terakhir, telah terjadi beberapa kasus korupsi terkait penyalahgunaan kekuasaan yang terjadi di beberapa desa di kabupaten Badung. Salah satunya terjadi di desa Mengwitani Badung. Perbekel Desa, Kepala Urusan (Kaur) Keuangan, dan bendahara desa diajukan ke persidangan dalam kasus dugaan korupsi pengelolaan keuangan Desa Mengwitani yang telah merugikan keuangan negara hingga Rp 1,2 miliar lebih (balipost.com, diakses 7 Agustus 2019).

Selain itu terjadi kasus serupa, yakni di desa Baha Badung. Oknum perbekel desa Baha dinyatakan terbukti bersalah melakukan tindak pidana korupsi APBDes secara berlanjut, hingga merugikan keuangan negara sebesar Rp 1 miliar lebih. Hal ini menunjukkan bahwa kinerja manajerial penyelenggara pemerintahan di desa tersebut tidak dilaksanakan dengan baik dan masih diragukan keseriusannya dalam mewujudkan visi dan misi organisasinya (balipost.com, diakses 7 Agustus 2019).

Menurut Handoko (1996) dalam meningkatkan efektivitas organisasi salah satu faktor yang dapat digunakan adalah kinerja manajerial. Kinerja manajerial 
sangat penting untuk menjalankan suatu organisasi agar dapat berjalan sesuai dengan rencana yang telah ditetapkan sebelumnya, untuk itu setiap penyelenggara pemerintahan harus memiliki kinerja manajerial demi menjaga nama baik suatu organisasi.

Lemahnya penerapan tata kelola di dalam pemerintahan menjadi pemicu terjadinya masalah pada instansi terkait dan menyadarkan akan perlunya sistem tata. Agar penyelenggaraan pemerintahan dapat dijalankan dengan baik maka perlu untuk menerapkan suatu tata kelola yang baik yang dikenal dengan istilah good governance. Dengan adanya good governance maka pemerintah diharapkan dapat mempertanggungjawabkan segala bentuk amanah yang telah diberikan kepadanya.

Penelitian Yusuf (2009) menunjukkan bahwa terdapat pengaruh yang signifikan antara penerapan good governance terhadap kinerja pemerintah Kota Bandung. Sedangkan menurut Hutapea dan Widyaningsih (2017) tidak terdapat pengaruh yang signifikan dari good government governance terhadap kinerja pemerintah daerah.

Selain dengan adanya good governance, motivasi juga dapat meningkatkan kinerja manajerial. Motivasi sangat penting tidak hanya bagi suatu individu, namun juga dapat bermanfaat bagi orang lain maupun organisasinya. Motivasi dapat dijadikan dasar untuk melakukan sesuatu, karena jika seseorang tidak memiliki motivasi maka akan memperlambat dalam pencapaian suatu tujuan. Dengan adanya motivasi, seseorang dapat tergerak untuk mempunyai keinginan di dalam mengerahkan segala kemampuannya untuk menyelesaikan pekerjaannya secara antusias.

Penelitian Karma dkk., (2016) mendapat hasil yang positif terkait pengaruh motivasi pada kinerja karyawan. Dengan demikian, jika motivasi yang dimiliki karyawan tergolong tinggi, maka kinerja karyawan akan meningkat. Sedangkan hasil penelitian Riyadi (2011) menunjukkan bahwa motivasi tidak mempunyai pengaruh positif terhadap kinerja manajerial.

Adanya hasil penelitian yang tidak konsistensi tersebut melatarbelakangi agar penelitian serupa dapat dilakukan kembali. Selain itu, kenyataan bahwa kinerja pemerintah desa di Kabupaten Badung dirasa masih perlu untuk dilakukan pembenahan agar nama baik Pemerintah Badung tetap terjaga.

Tujuan dari penelitian ini adalah untuk membuktikan pengaruh dari good governance dan motivasi kerja terhadap kinerja manajerial Penyelenggara Pemerintahan Desa di Kabupaten Badung. Penelitian ini diharapkan dapat memberikan wawasan mengenai kontribusi dari teori keagenan, dapat menjadi referensi bagi penelitian selanjutnya dan dapat memberikan sumbangsih pemikiran terhadap peningkatan kinerja manajerial bagi instansi terkait.

Berdasarkan teori keagenan yang dikemukakan oleh (Jensen and Meckling, 1976), organisasi perusahaan merupakan jaringan kontraktual antara prinsipal dan agen. Sebagai agen, pemerintah hendaknya selalu melaksanakan apa yang menjadi kepentingan para prinsipalnya yakni masyarakat. Kewajiban pemerintah dalam memberikan informasi harus dilaksanakan demi memenuhi hak masyarakat untuk memperoleh informasi. Pemerintah yang menerapkan good governance diharapkan mampu mendukung kelancaran pelaksanaan tugas dan fungsi di dalam penyelenggaraan pemerintahan. 
Penelitian Zeyn (2011) menunjukkan bahwa penerapan good governance memiliki pengaruh yang signifikan terhadap akuntabilitas keuangan pemerintah Kota Bandung, artinya good governance memiliki pengaruh terhadap kinerja pemerintahan. Penelitian Widasari dan Putri (2018) menujukkan bahwa good governance bernilai positif terhadap kinerja manajerial. Hal ini berarti bahwa penerapan good governance berpengaruh positif terhadap kinerja manajerial penyelenggara pemerintahan desa di Kabupaten Badung. Selain itu, Putra (2018) dan Acintya dan Putri (2015) menyatakan bahwa good governance berpengaruh positif pada kinerja pemerintah. Hasil penelitian Darwanis dkk., (2015) menyatakan bahwa peningkatan pemahaman prinsip-prinsip good governance berpengaruh pada kinerja aparatur pemerintah daerah Kabupaten Bireuen. Berdasarkan penjelasan di atas, berikut ini hipotesisnya:

$\mathrm{H}_{1}$ : Good governance berpengaruh positif terhadap kinerja manajerial.

Motivasi adalah faktor-faktor yang ada dalam diri seseorang yang menggerakkan, mengarahkan perilakunya untuk memenuhi tugas tertentu (Ardana dkk., 2009). Motivasi didefinisikan sebagai proses yang menjelaskan mengenai kekuatan, arah, dan ketekunan seseorang dalam upaya untuk mencapai tujuan.

Dengan adanya kontrak berdasarkan teori keagenan maka agen berusaha untuk termotivasi agar dapat meningkatkan kinerjanya sehingga tetap terlihat baik oleh prinsipal. Motivasi dapat memberi energi dan penyebab utama pergerakan organisme hidup termasuk manusia. Karena motivasi akan mengarah pada kenyataan bahwa seseorang tetap berkomitmen untuk tugasnya dan melakukan pekerjaannya dengan serius dan penuh sukacita. Salah satu alasan kesuksesan karyawan adalah adanya faktor motivasi pada tingkat tinggi dalam organisasi tersebut.

Penelitian sebelumnya dilakukan oleh Caroline (2013) dan Mia (1998) yang menyatakan bahwa motivasi berpengaruh positif dan signifikan terhadap kinerja manajerial. Penelitian (Handoyo et al., 2015) menyatakan bahwa terdapat hubungan positif antara motivasi kerja dengan kinerja karyawan. Penelitian Elqadri et al., (2015) dan Zameer et al., (2014) mengenai pengaruh motivasi pada kinerja karyawan memperoleh hasil positif. Ini menunjukkan bahwa semakin tinggi motivasi yang dimiliki karyawan maka kinerja karyawan akan semakin meningkat. Choong et al., (2011) menganalisis pengaruh motivasi terhadap kinerja secara empiris membuktikan bahwa motivasi memilik pengaruh positif pada kinerja. Berdasarkan penjelasan tersebut, hipotesisnya adalah sebagai berikut:

$\mathrm{H}_{2}$ : Motivasi kerja berpengaruh positif terhadap kinerja manajerial.

\section{METODE PENELITIAN}

Penelitian ini dilakukan pada Pemerintahan Desa di Kabupaten Badung yang terdiri dari 46 Kantor Desa. Lokasi ini dipilih karena berdasarkan fenomena yang ada serta terkait responden sebagai pemerintah desa selaku pengelola dana desa masih sedikit yang melakukan penelitian. Dengan pertimbangkan tersebut, penulis ingin membuktikan pengaruh kedua faktor tersebut terhadap kinerja manajerial penyelenggara pemerintahan desa yang terdapat di Kabupaten Badung. 
Menurut Mardiasmo (2004:17) tujuan pembangunan sektor publik adalah untuk mewujudkan good governance, yang sering diartikan sebagai kepemerintahan yang baik. Tata kelola pemerintahan ini menekankan pada cara pemerintah dalam mengelola sumber daya yang ada dalam pengelolaan negara. Instrumen dalam penelitian ini diambil dari penelitian Acintya dan Putri (2015), indikator yang digunakan adalah partisipasi, taat hukum, transparansi, daya tanggap, kesetaraan, efektivitas dan efisiensi, akuntabilitas, dan visi strategik.

Menurut Guven (2013) motivasi merupakan sebuah dorongan yang membuat seseorang memiliki keinginan untuk bertindak dan bekerja sama dengan orang lain, bekerja secara terintegrasi, dan efektif untuk memperoleh sebuah kepuasan. Jika seseorang memiliki motivasi yang cenderung rendah maka secara tidak langsung semangat yang dimiliki juga rendah. Sehingga hal tersebut dapat menghambat tercapainya tujuan organisasi. Indikator variabel motivasi kerja terdiri dari motivasi kebutuhan akan prestasi, motivasi kebutuhan akan kekuasaan, dan motivasi kebutuhan akan afiliasi yang diadopsi dari penelitian Supono (2014).

Kinerja manajerial merupakan salah satu faktor yang dapat dipakai untuk meningkatkan efektivitas organisasi (Handoko, 1996). Dalam mencapai suatu tujuan organisasi agar sesuai rencana yang telah ditetapkan maka diperluka adanya kinerja maanajerial. Pengukuran instrumen penelitian diambil dari penelitian Giri (2014) dengan indikator yakni perencanaan, investigasi, koordinasi, evaluasi, pengawasan, pengaturan staf, negosiasi, perwakilan, dan kinerja secara keseluruhan.

Populasi dalam penelitian ini adalah penyelenggara pemerintahan di 46 desa di Kabupaten Badung. Sedangkan sampel yang digunakan dalam penelitian ini adalah setiap desa ditentukan 5 orang penyelenggara pemerintahan desa yang terdiri dari Perbekel, Sekretaris Desa, Kepala Urusan, Kepala Seksi dan staf.

Penelitian ini menggunakan uji validitas dan uji reliabilitas terhadap kuesioner untuk mengetahui layak atau tidaknya kuesioner tersebut dijadikan sebagai instrumen penelitian. Selanjutnya akan dilakukan uji asumsi klasik dan teknik analisis data. Teknik analisis data yang digunakan dalam penelitian ini adalah analisis regresi linear berganda, karena terdiri dari dua variabel independen. Adapun rumus persamaan dari regresi linear berganda yang digunakan dalam penelitian ini adalah :

$$
Y=\alpha+\beta_{1} X_{1}+\beta_{2} X_{2}+\varepsilon
$$

Keterangan :

$\begin{array}{ll}\mathrm{Y} & =\text { Kinerja manajerial } \\ \mathrm{a} & =\text { Konstanta } \\ \beta_{1}, \beta_{2} & =\text { Koefisien regresi } \\ \mathrm{X}_{1} & =\text { Good Governance } \\ \mathrm{X}_{2} & =\text { Motivasi kerja } \\ \varepsilon & =\text { Standard error }\end{array}$




\section{HASIL DAN PEMBAHASAN}

Pengujian yang dilakukan pertama kali pada penelitian ini yakni uji instrumen. Uji instrumen dilakukan untuk menguji kelayakan kuesioner, yang terdiri dari uji validitas dan uji reliabilitas. Uji validitas digunakan untuk mengukur sah, atau valid tidaknya suatu kuesioner. Hasil Perason's Correlation dalam uji validitas ini untuk variabel good governance sebesar 0,535-0,652, variabel motivasi kerja sebesar 0,556-0,504, dan variabel kinerja manajerial sebesar 0,619-0,708. Hasil tersebut menunjukkan nilai pearson's correlation yang lebih besar dari 0,30 sehingga ketiga variabel dalam kuesioner tersebut dinyatakan valid.

Uji reliabilitas digunakan untuk mengetahui tingkat ketepatan, keakuratan, dan konsistensi kuesioner jika digunakan dua kali atau lebih pada penelitian lainnya. Hasil menunjukkan bahwa nilai cronbach's alpha masing-masing variabel memiliki nilai lebih besar dari 0,70, sehingga pernyataan dalam kuesioner penelitian dinyatakan reliabel.

Berikut ini hasil dari statistik deskriptif dapat dilihat pada Tabel 2.

Tabel 2. Hasil Statistik Deskriptif

\begin{tabular}{lccccc}
\hline \multicolumn{1}{c}{ Variabel } & $\mathrm{N}$ & Minimum & Maksimum & Rata-rata & Std. Deviasi \\
\hline Good Governance $\left(\mathrm{X}_{1}\right)$ & 230 & 52,00 & 75,00 & 64,88 & 5,489 \\
Motivasi Kerja $\left(\mathrm{X}_{2}\right)$ & 230 & 44,00 & 80,00 & 63,16 & 6,425 \\
Kinerja Manajerial $(\mathrm{Y})$ & 230 & 34,00 & 50,00 & 42,14 & 3,860 \\
\hline
\end{tabular}

Sumber: Data Penelitian, 2019

Berdasarkan Tabel 2 untuk variabel good governance $\left(\mathrm{X}_{1}\right)$ mendapat nilai minimum sebesar 52, nilai maksimum sebesar 75 , dan nilai rata-rata sebesar 64,88 . Hal ini berarti jika jumlah skor jawaban responden lebih besar dari 64,88 maka termasuk pada responden yang memiliki tingkat good governance yang tinggi. Jika lebih kecil dari 64,88 maka termasuk pada responden yang memiliki good governance yang rendah dengan penyimpangan sebesar 5,489.

Variabel motivasi kerja $\left(X_{2}\right)$ mendapat nilai minimum sebesar 44 , nilai maksimum sebesar 80 , dan nilai rata-rata sebesar 63,16 . Hal ini berarti jika jumlah skor jawaban responden lebih besar dari 63,16 maka termasuk pada responden yang memiliki tingkat motivasi kerja yang tinggi. Jika skor jawaban lebih kecil dari 63,16 maka termasuk pada responden yang memiliki tingkat motivasi kerja yang rendah dengan penyimpangan sebesar 6,425.

Variabel kinerja manajerial (Y) mendapat nilai minimum sebesar 34, nilai maksimum sebesar 50, dan nilai rata-rata sebesar 42,14. Hal ini berarti jika jumlah skor jawaban responden lebih besar dari 42,14 maka termasuk pada responden yang memiliki tingkat kinerja yang tinggi. Jika lebih kecil dari 42,14 maka termasuk pada responden yang memiliki tingkat kinerja yang rendah dengan penyimpangan sebesar 3,860.

Uji normalitas bertujuan untuk menguji apakah dalam model regresi yang dibuat memiliki distribusi yang normal atau tidak. Tabel 3 menyajikan hasil yang didapatkan dari uji normalitas.

Tabel 3. Hasil Uji Normalitas

\begin{tabular}{lr}
\hline Kolmogorov-Smirnov Z & 0,052 \\
Asymp.Sig.(2-tailed) & 0,200 \\
\hline
\end{tabular}

Sumber: Data Penelitian, 2019 
Berdasarkan Tabel 3 hasil Asymp. Sig.(2-tailed) sebesar 0,200 lebih besar dari level of significant sebesar 0,05 sehingga dapat disimpulkan bahwa model regresi memiliki distribusi yang normal.

Uji multikolinearitas digunakan untuk mengetahui adanya korelasi antara variabel independen. Seharusnya tidak terdapat hubungan dalam model regresi.

Hasil uji multikolinearitas dapat dilihat pada Tabel 4.

Tabel 4. Hasil Uji Multikolinearitas

\begin{tabular}{lccc}
\hline \multirow{2}{*}{ Model } & Collinearity & Statistics & \multirow{2}{*}{ Keterangan } \\
\cline { 2 - 3 } & Tolerance & VIF & \\
\hline Good Governance $\left(\mathrm{X}_{1}\right)$ & 0,890 & 1,124 & Tidak ada multikolinearitas \\
Motivasi Kerja $\left(\mathrm{X}_{2}\right)$ & 0,890 & 1,124 & Tidak ada multikolinearitas \\
\hline
\end{tabular}

Sumber: Data Penelitian, 2019

Berdasarkan tabel tersebut, nilai tolerance dari variabel good governance dan variabel motivasi kerja adalah sama sebesar 0,890 dimana nilai tersebut lebih besar dari $10 \%$. Sedangkan nilai VIF dari variabel good governance dan motivasi kerja adalah sama sebesar 1,124 dimana nilai tersebut lebih kecil dari 10 . Sehingga disimpulkan bahwa antara variabel independen tidak terdapat gejala multikolinearitas.

Uji heteroskedastisitas bertujuan menguji terjadinya ketidaksamaan variance dari satu pengamatan ke pengamatan lain dalam model regresi. Berikut ini hasil dari uji heteroskedastisitas.

Tabel 5. Hasil Uji Heteroskedastisitas

\begin{tabular}{ccc}
\hline Model & Sig. & Keterangan \\
\hline Good Governancee $\left(\mathrm{X}_{1}\right)$ & 0,078 & Bebas Heterokedastisitas \\
Motivasi Kerja $\left(\mathrm{X}_{2}\right)$ & 0,637 & Bebas Heterokedastisitas \\
\hline
\end{tabular}

Sumber : Data Penelitian, 2019

Berdasarkan Tabel 5 hasil pengujian menunjukkan bahwa tingkat signifikansi semua variabel berada diatas 0,05. Hal ini menunjukkan bahwa model regresi bebas dari masalah heteroskedastisitas.

Analisis regresi linear berganda dilakukan untuk mengetahui pengaruh antar variabel independen dan variabel dependen. Berikut ini hasil dari analisis regresi linear berganda.

Tabel 6. Hasil Analisis Regresi Linear Berganda

\begin{tabular}{lccccc}
\hline \multirow{2}{*}{ Model } & \multicolumn{2}{c}{$\begin{array}{c}\text { Unstandardized } \\
\text { Coefficients }\end{array}$} & $\begin{array}{c}\text { Standardized } \\
\text { Coefficients }\end{array}$ & T & Sig. \\
\cline { 2 - 6 } & $\mathrm{B}$ & Std. Error & Beta & & \\
\hline (Constant) & 15,227 & 2,931 & & 5,194 & 0,000 \\
Good Governance $\left(\mathrm{X}_{1}\right)$ & 0,250 & 0,042 & 0,355 & 5,914 & 0,000 \\
Motivasi Kerja $\left(\mathrm{X}_{2}\right)$ & 0,170 & 0,036 & 0,283 & 4,710 & 0,000 \\
Adjusted $\boldsymbol{R}^{2}$ & 0,266 & & & & \\
F Hitung & 42,488 & & & & \\
Sig. F & 0,000 & & & & \\
Sumber: Data Pen & & & & & \\
\hline
\end{tabular}

Sumber: Data Penelitian, 2019

Berdasarkan hasil dari Tabel 6 tersebut maka berikut dirumuskan persamaannya:.

$$
\mathrm{Y}=15,227+0,250 \mathrm{X}_{1}+0,170 \mathrm{X}_{2}+\varepsilon
$$

Koefisien determinasi $\left(\mathrm{R}^{2}\right)$ mengukur kemampuan model dalam menjelaskan variabel dependen. Nilai koefisien determinasi yang digunakan 
dalam penelitian ini adalah nilai dari Adjusted $\mathrm{R}^{2}$ yaitu sebesar 0,266 . Hal ini berarti bahwa variabel good governance dan motivasi kerja berkontribusi pengaruhnya sebesar 26,6 persen terhadap kinerja manajerial dan sisanya sebesar 83,4 persen dipengaruhi variabel lainnya yang tidak terdapat ke dalam model di penelitian ini.

Uji kelayakan model (Uji F) digunakan untuk mengetahui kelayakan model regresi dalam menguji pengaruh variabel independen terhadap variabel dependen. Berdasarkan tabel 6, menunjukkan hasil bahwa nilai $F_{\text {hitung sebesar }}$ 42,488 dengan nilai signifikansi F sebesar 0,000 yang lebih kecil dari 0,05. Hasil ini bermakna bahwa variabel good governance dan variabel motivasi kerja mempu memprediksi atau menjelaskan fenomena terkait kinerja manajerial yang terdapat di pemerintahan desa.

Hasil pengujian hipotesis pertama $\left(\mathrm{H}_{1}\right)$ mengenai pengaruh good governance terhadap kinerja manajerial menunjukkan nilai signifikansi sebesar 0,000 yang lebih kecil dari nilai $a=0,05$. Oleh karena itu, hipotesis pertama yang terdapat dalam penelitian ini diterima. Hal tersebut menunjukkan bahwa penerapan good governance memiliki pengaruh yang positif terhadap kinerja manajerial Penyelenggara Pemerintahan Desa di Kabupaten Badung. Jika penerapan good governance semakin tinggi, maka secara tidak langsung akan semakin tinggi pula kinerja manajerial yang dimiliki oleh Penyelenggara Pemerintahan Desa yang terdapat di Kabupaten Badung.

Sejalan dengan teori keagenan yang menjelaskan bahwa good governance adalah cara yang dapat dilakukan dalam mengelola suatu perusahaan atau organisasi agar dapat berjalan secara efektif dan efisien untuk mencapai suatu tujuan yang telah ditetapkan dari organisasi. Bagi pemerintah yang mempraktikkan good governance ini diharapkan mampu mendukung kelancaran dan kepatuhan dari pelaksanaan tugas dan fungsinya sebagai penyelenggara pemerintahan sebagai agar berjalan dengan efektif dan efisien.

Salah satu manfaat yang bisa dipetik dari adanya good governance ini adalah meningkatkan kinerja melalui proses pengambilan keputusan yang lebih baik, meningkatkan efisiensi operasional, serta meningkatkan pelayanan yang diberikan kepada publik (FCGI, 2002). Jika tata kelola pemerintahan sudah baik maka hal tersebut dapat menunjukkan tanggung jawab pemerintah yang lebih besar, sehingga kinerja pemerintah ini diharapkan mengalami peningkatan.

Hasil penelitian ini juga didukung oleh penelitian (Darwanis, Aliamin, dan Amrullah, 2015) yang menyatakan bahwa peningkatan pemahaman prinsipprinsip good governance berpengaruh pada kinerja aparatur pemerintah daerah Kabupaten Bireuen. Selain itu, Putra (2018) dan Acintya dan Putri (2015) menyatakan bahwa good governance berpengaruh positif pada kinerja pemerintah.

Berdasarkan tabel 6 hasil pengujian hipotesis kedua mengenai pengaruh motivasi kerja terhadap kinerja manajerial penyelenggara pemerintahan desa memperoleh nilai signifikansi yakni sebesar 0,000 yang lebih kecil dari nilai $\alpha=$ 0,05 . Oleh karena itu, hipotesis kedua dalam penelitian ini dinyatakan diterima. Hal tersebut menunjukkan bahwa penerapan motivasi kerja memiliki pengaruh yang positif terhadap kinerja manajerial Penyelenggara Pemerintahan Desa di Kabupaten Badung. Jika tingkat motivasi semakin tinggi, maka akan dapat 
meningkatkan kinerja manajerial yang dimiliki oleh Penyelenggara Pemerintahan Desa yang terdapat di Kabupaten Badung.

Dengan adanya kontrak berdasarkan dari teori keagenan maka dalam hal ini agen berusaha untuk selalu termotivasi agar dapat meningkatkan kinerjanya sehingga akan tetap terlihat baik oleh prinsipal. Temaja (2016) menyatakan bahwa diperlukan adanya pembinaan dan motivasi kerja karyawan untuk menumbuhkan komitmen yang kuat dalam rangka meningkatkan prestasi kerjanya. Salah satu kesuksesan karyawan adalah adanya faktor motivasi pada tingkat yang tinggi dalam organisasi tersebut (Azar dan Shafighi, 2013). Dengan demikian, maka motivasi adalah faktor penting bagi suatu perusahaan untuk mendorong kinerja karyawannya sehingga tujuan atau sasaran yang telah ditetapkan oleh perusahaan dapat terwujudkan.

Hasil penelitian ini juga didukung oleh penelitian (Handoyo et al., 2015) menyatakan bahwa terdapat hubungan positif motivasi kerja dengan kinerja karyawan. Elqadri et al., (2015) dan Zameer et al., (2014) mendapatkan hasil yang positif terkait pengaruh motivasu pada kinerja karyawan. Hal ini menunjukkan bahwa semakin tinggi motivasi yang dimiliki karyawan akan meningkatkan kinerja yang dimiliki oleh karyawan tersebut.

Berdasarkan hal tersebut maka pemerintah hendaknya perlu memperhatikan aspek-aspek yang terkandung dalam good governance terkait bagaimana menjaga hubungan baik dengan masyarakat, menjaga kepercayaan dari masyarakat, dan melibatkan masyarakat dalam kegiatan terkait pemerintahan desa. Agar senantiasa pemerintah selalu dapat menunjukkan kinerja yang baik kepada masyarakat.

Selain itu juga agar kedepannya pemerintah desa selalu memiliki motivasi yang tinggi. Dengan memiliki motivasi yang tinggi pemerintah diharapkan dapat memiliki semangat yang tinggi pula dalam melaksanakan seluruh tugas yang menjadi tanggungjawabnya. Sehingga secara tidak langsung hal tersebut dapat meningkatkan kinerja manajerial dalam rangka mencapai tujuan dari suatu organisasi.

\section{SIMPULAN}

Berdasarkan hasil analisis data dan pembahasan di atas, maka dapat ditarik kesimpulan: 1) Good governance memiliki pengaruh yang positif terhadap kinerja manajerial Penyelenggara Pemerintahan Desa di Kabupaten Badung. Hal ini berarti semakin baik penerapan dari good governance di dalam mewujudkan kinerja manajerial pemerintah, akan semakin baik kinerja manajerial yang dimiliki oleh Penyelenggara Pemerintahan Desa khususnya yang terdapat di kabupaten Badung. 2) Motivasi kerja memiliki pengaruh yang positif terhadap kinerja manajerial Penyelenggara Pemerintahan Desa yang terdapat di Kabupaten Badung. Hal ini berarti semakin tinggi tingkat motivasi kerja yang dimiliki oleh pemerintah, maka akan dapat meningkatkan kinerja manajerial dari pemerintah desa tersebut.

Oleh karena penelitian ini hanya dilakukan pada Pemerintahan desa yang terdapat di Kabupaten Badung saja, maka untuk penelitian yang akan dilakukan selanjutnya agar lebih memperluas lagi populasi yang akan digunakan dan menambah variabel lainnya yang berpengaruh namun tidak terdapat dalam 
penelitian ini. Selain itu juga, karena dalam penelitian ini hanya menggunakan variabel kinerja manajerial non keuangan, yang dalam hal ini lebih kepada teknis terhadap kinerja manajerial. Maka penelitian selanjutnya disarankan untuk mengguankan variabel kinerja manajerial baik terkait keuangan maupun non keuangan.

\section{REFERENSI}

Acintya, I. G. A. A. D., \& Putri, I. G. A. M. A. D. (2015). Kinerja Pemerintah Kota Denpasar dalam Implementasi SAKIP dan Penerapan Good Governance. EJurnal Akuntansi Universitas Udayana, 12(2), 233-248.

Ardana, K., Mujiati, N. W., \& Sriathi, A. A. A. (2009). Perilaku Keorganisasian (Edisi 2). Yogyakarta: Graha Ilmu.

Azar, M., \& Shafighi, A. A. (2013). The Effect of Work Motivation on Employees' Job Performance (Case Study: Employees of Isfahan Islamic Revolution Housing Foundation). International Journal of Academic Research in Business and Social Sciences, 3(9), 432-445. https:// doi.org/10.6007/ijarbss/v3-i9/231

Caroline, S. A. (2013). Pengaruh Partisipasi Anggaran, Motivasi Dan Evaluasi Terhadap Kinerja Manajerial (Studi Empiris Pada Pemerintahan Kabupaten Situbondo). Skripsi Fakultas Ekonomi Universitas Jember.

Choong, Y.-O., Wong, K.-L., \& Lau, T.-C. (2011). Intrinsic Motivation and Organizational Commitment in the Malaysian Private Higher Education Institutions : an Empirical Study. Jurnal Researchers World, 2(4), 40-50.

Darwanis, Aliamin, \& Amrullah, M. (2015). Pengaruh Capacity Building Pada Pemahaman Prinsip Good Governance Dalam Meningkatkan Kinerja Aparatur. Jurnal Ilmiah Akuntansi Dan Bisnis, 10(1), 55-68.

Elqadri, Z. M., Priyono, Suci, R. P., \& Chandra, T. (2015). Effect of Leadership Style, Motivation, and Giving Incentives on the Performance of Employees-PT. Kurnia Wijaya Various Industries. International Education Studies, 8(10), 183-192. https:/ / doi.org/10.5539/ies.v8n10p183

FCGI (Forum for Corporate Governance in Indonesia). (2002). Tata Kelola Perusahaan (Corporate Governance) the Essence of Good Corporate Governance. Konsep dan Implementasi Perusahaan Publik dan Korporasi Indonesia. Jakarta: Yayasan Pendidikan Pasar Modal Indonesia \& Synergy Communication.

Giri, M. D. B. W., \& Dwirandra, A. A. B. (2014). Keadilan Distributif, Keadilan Prosedural, dan Komitmen Tujuan Anggaran Sebagai Pemediasi Partisipasi Penganggaran Pada Kinerja Manajerial. E-Jurnal Akuntansi Universitas Udayana, 3(4), 208-226.

Guven, G. O. (2013). Challenges in Achieving High Motivation and Performance in Educational Management: Case Study of a North Cyprus Public High School. International Journal of Humanities and Social Science, 3(6), 20-26.

Handoko, T. H. (1996). Manajemen. Yogyakarta: BPFE.

Handoyo, L. N., Hamid, D., \& Iqbal, M. (2015). The Influence of Leadership Styles on Employee's Performance Through Work Motivation (An Organizational Study at Four Hotels In Malang). Journal Administrasi Bisnis (JAB), 22(1), 1-7. https://doi.org/10.1017/CBO9781107415324.004

Hutapea, F. L., \& Widyaningsih, A. (2017). Pengaruh Good Government Governance dan Ukuran Legislatif Terhadap Kinerja Pemerintah Daerah 
(Studi Pada Pemerintah Provinsi di Indonesia). Jurnal Aset (Akuntansi Riset) Universitas Pendidikan Indonesia. Bandung, 9(1), 173-186. https://doi.org/10.17509/jaset.v9i1.5446

Jensen, M. C., \& Meckling, W. H. (1976). Theory of the Firm: Managerial Behavior, Ageny Costs and Ownership Structure. Journal of Financial Economics 3, 305-360.

Karma, K. F. A., Yasa, G. W., \& Ratnadi, N. M. D. (2016). Pengaruh Gaya Kepemimpinan Situasional, Budaya Organisasi dan Motivasi Pada Kinerja Karyawan di PT Bank Pembangunan Daerah Bali Cabang Badung. E-Jurnal Akuntansi Dan Bisnis Universitas Udayana, 5(11), 3823-3856.

Mardiasmo. (2004). Akuntansi Sektor Publik. Yogyakarta: Andi.

Mia, L. (1998). Managerial Attitude, Motivation and Effectiveness of Budget Participation. Accounting Organization and Society, 13(5), 465-475.

Miasa. (2017). Bendahara Desa Mengwitani Diadili Kasus Korupsi. Bali Post. Retrieved from http://www.balipost.com/news/2017/11/17/28352/Bendahara-DesaMengwitani-Diadili-Kasus...html

Miasa. (2019). Sidang Korupsi APBDes, Oknum Perbekel Baha Dipenjara 4,5 Tahun. Bali Post. Retrieved from http://www.balipost.com/news/2019/02/13/68750/Sidang-KorupsiAPBDes,Oknum-Perbekel...html

Putra, I. G. A. S., \& Putra, I. M. P. D. (2018). Pengaruh Good Governance dan Sistem Pengendalian Intern Pemerintah Pada Kinerja Pemerintah Daerah. EJurnal Akuntansi Universitas Udayana, 25(3), 1720-1743.

Riyadi, S. (2011). Pengaruh Kompensasi Finansial, Gaya Kepemimpinan, dan Motivasi Kerja Terhadap Kinerja Karyawan pada Perusahaan Manufaktur di Jawa Timur. Jurnal Manajemen Dan Kewirausahaan, 13(1), 40-45. https:// doi.org/10.9744/jmk.13.1.40-45

Temaja, I., \& Utama, I. (2016). Pengaruh Profesionalisme, Kepribadian Hardiness, Motivasi dan Budaya Organisasi Pada Kinerja Auditor di Kantor Akuntan Publik. E-Jurnal Akuntansi Universitas Udayana, 15(3), 1711-1739.

Undang-Undang Republik Indonesia Nomor 6 Tahun 2014 Tentang Desa. (n.d.).

Widasari, K. I., \& Putri, I. G. A. M. A. D. (2018). Pengaruh Good Governance dan Budaya Organisasi Terhadap Kinerja Manajerial Penyelenggara Pemerintahan Desa di Kabupaten Badung. E-Jurnal Akuntansi Universitas Udayana, 22(2), 1308-1334. https:// doi.org/10.24843/eja.2018.v22.i02.p18

www.bali.bps.go.id. (n.d.). Retrieved from https://bali.bps.go.id/

www.kemenkeu.go.id. (n.d.). from https://www.kemenkeu.go.id/media/6750/buku-saku-dana-desa.pdf

Yusuf, D. S. (2009). Pengaruh Good Governance Terhadap Kinerja Pemerintah Daerah Kota Bandung. Tugas Penelitian Jurusan Akuntansi Politeknik Pos Indonesia Bandung.

Zameer, H., Ali, S., Nisar, W., \& Amir, M. (2014). The Impact of the Motivation on the Employee's Performance in Beverage Industry of Pakistan. International Journal of Academic Research in Accounting, Finance and Management Sciences, 4(1), 293-298. https://doi.org/10.6007/ijarafms/v4$\mathrm{i} 1 / 630$ 
Zeyn, E. (2011). Pengaruh Penerapan Good Governance dan Standar Akuntansi Pemerintahan Terhadap Akuntabilitas Keuangan Dengan Komitmen Organisasi Sebagai Pemoderasi. Jurnal Reviu Akuntansi Dan Keuangan, 1(1), 21-37. 